\title{
THE DISTRIBUTION OF ABO BLOOD GROUPS IN A SAMPLE OF HOSPITAL PATIENTS RECEIVING BLOOD TRANSFUSIONS
}

\author{
JOHN BUETTNER-JANUSGH \\ Laboratory of Physical Anthropology, University of Michigan
}

At the present time there is great interest in efforts to increase our understanding of the nature of the selective agents which act on the ABO blood group system. Brues ('54) presents many of the arguments in support of the view that the $A B O$ genes are subject to natural selection. The foundations for work on the physiological functions of this genetic system and the selective mechanisms that operate on it were laid many years ago by investigators such as Ehrlich and Morgenroth ('00) and Dienst ('05). Dienst proposed that eclampsia was due to antagonism between the blood of the fetus and its mother. He compared the process resulting in eclampsia to blood transfusions between different mammalian species. The response to this idea was typified by Liepmann ('05) who declared that this was a "biological monstrosity." It was unthinkable that a mother's blood would damage the child she was carrying.

Since the Hirzsfelds ('19) demonstrated that there are differences in $\mathrm{ABO}$ frequencies among various populations and racial groups, the discovery of more differences in population $\mathrm{ABO}$ frequencies and their use as racial criteria have become anthropological traditions. The literature contains reports of the $A B O$ distribution in thousands of human groups, based on samples ranging in size from fifty to over two hundred thousand. Yet none of these studies describes the $\mathrm{ABO}$ frequencies with respect to the age and sex composition of the population tested. Glass ('54) points out that 
most of these investigations not only fail to group the data by age or sex but also they are usually not based upon random samples. Yet such data and analyses are essential if selection on a genetic system is to be demonstrated. Furthermore, we seldom find information about the physical fitness or demographic status of the individuals tested. An examination of Boyd's famous compilation ('39) shows that there are differences in frequencies of the four $A B O$ phenotypes in groups taken from mental hospitals, tuberculosis sanatoria, and military recruiting offices. Boyd's sources, however, do not give sufficient information about the condition of the individuals so hospitalized or recruited to warrant further analysis. It seems reasonable to conclude that most investigators excluded the possibility that selection exists from their approach to the ABO system (e.g., Manuila, '56).

The importance of the $\mathrm{ABO}$ system to forensic medicine and its apparent usefulness in racial classifications are probably further reasons that this system has been regarded as resistant or immune to selection. Its immutability and stable properties have been emphasized repeatedly by physicians and anthropologists (Verzar, '22). Another factor has been the emphasis by anthropologists on the use of nonadaptive traits, that is, traits not subject to selection, as racial markers. Boyd ('53), among others, discusses the difficulties the concept of non-adaptive traits make for sound evolutionary theory.

This report describes an analysis of the $A B O$ blood group distribution in a large sample of hospital patients, which was undertaken in order to discover if, in fact, sick people differ from others with respect to the $A B O$ frequencies. We reversed the usual study in which donors to a blood bank are analyzed and instead took for our sample the persons receiving transfusions.

The results have implications for understanding of the mechanisms of selection on the $\mathrm{ABO}$ system and for the use of the ABO blood group frequencies in anthropological studies. 
This study was supported, in part, by a grant from the Horace H. Rackham School of Graduate Studies of the University of Michigan. F.P. Thieme secured IBM statistical machines with which to analyze the data. W. J. Schull provided invaluable advice on statistical methods. J. V. Neel assisted in obtaining critical hospital records. The personnel of the blood bank and the tabulating service of University Hospital, Ann Arbor, Michigan, co-operated in the collection of the data.

\section{MATERIALS AND METHODS}

Relevant data were recorded for all in-patients who received blood from the blood bank at University Hospital, Ann Arbor, Michigan, between 1 January, 1952, and 31 December, 1953. The information on 10,368 individual records taken from the blood bank included only the ABO type of the persons receiving transfusions. In order to get data on the age, sex, and disease of these patients the diagnostic records of the hospital had to be searched. Approximately 200,000 diagnostic records were examined in order to obtain these data. The following information was then available for each transfused patient: age, sex, race, county or state of residence, services to which admitted, each specific diagnosis, kinds of therapy, status upon discharge (ranging from improved to dead), x-ray therapy if any, death, and results of a Kahn test. The total size of the sample was reduced to 7747 after duplicate entries and individuals listed as "black" had been removed. "Black" individuals, so listed by admissions clerks, comprised less than $10 \%$ of the sample. The numbers reported in the analysis discussed below were obtained with the use of an IBM counting sorter.

First, we specificed the age distribution with the four ABO blood groups. The cards were sorted into nine age groups, 0-1 year, 1-10, 11-20, 21-30, 31-40, 41-50, 51-60, 61-70, 71 and older. Then, a chi-square test for homogeneity by age 
was run. The distribution by age is shown in table 1 . The chi-square value, 42.4051 with 24 degrees of freedom, is significant $(.01<\mathrm{p}<.02)$, implying differences with respect to age in the distribution of the $\mathrm{ABO}$ groups within this

TABLE 1

$A B O$ blood groups and sex ratios distributed among nine age groups

\begin{tabular}{|c|c|c|c|c|c|c|}
\hline AGI GROUPS & & $\mathbf{0}$ & $A$ & B & $\mathbf{A B}$ & TOTALS \\
\hline \multirow[t]{3}{*}{$0-1$} & Males & 115 & 109 & 27 & 10 & 261 \\
\hline & Females & 67 & $5 \overline{5}$ & 14 & 5 & 141 \\
\hline & Sex ratio & 1.716 & 1.982 & 1.928 & 2.000 & 1.901 \\
\hline \multirow[t]{3}{*}{$1-10$} & Males & 141 & 153 & 32 & 23 & 349 \\
\hline & Females & 100 & 122 & 26 & 13 & 261 \\
\hline & Sex ratio & 1.410 & 1.254 & 1.231 & 1.769 & 1.416 \\
\hline \multirow[t]{3}{*}{$11-20$} & Males & 135 & 130 & 35 & 14 & 314 \\
\hline & Females & 117 & 113 & 29 & 20 & 279 \\
\hline & Sex ratio & 1.154 & 1.150 & 1.207 & 0.700 & 1.125 \\
\hline \multirow[t]{3}{*}{$21-30$} & Males & 290 & 124 & 36 & 16 & 466 \\
\hline & Females & 235 & 251 & 66 & 25 & 577 \\
\hline & Sex ratio & 1.234 & 0.494 & 0.545 & 0.640 & 0.728 \\
\hline \multirow[t]{3}{*}{$31-40$} & Males & 179 & 179 & 45 & 19 & 422 \\
\hline & Females & 265 & 247 & 59 & 15 & 586 \\
\hline & Sex ratio & 0.675 & 0.725 & 0.763 & 1.276 & 0.857 \\
\hline \multirow[t]{3}{*}{$41-50$} & Males & 204 & 220 & 64 & 20 & 508 \\
\hline & Females & 262 & 243 & 75 & 27 & 607 \\
\hline & Sex ratio & 0.779 & 0.905 & 0.853 & 0.741 & 0.819 \\
\hline \multirow[t]{3}{*}{$51-60$} & Males & 281 & 280 & 62 & 22 & 645 \\
\hline & Females & 190 & 202 & 51 & 29 & 472 \\
\hline & Sex ratio & 1.479 & 1.386 & 1.216 & 0.759 & 1.210 \\
\hline \multirow[t]{3}{*}{$61-70$} & Males & 313 & 278 & 74 & 27 & 692 \\
\hline & Females & 195 & 179 & 36 & 22 & 432 \\
\hline & Sex ratio & 1.605 & 1.553 & 2.055 & 1.227 & 1.610 \\
\hline \multirow[t]{3}{*}{$71-$} & Males & 225 & 196 & 53 & 16 & 490 \\
\hline & Females & 98 & 109 & 28 & 10 & 245 \\
\hline & Sex ratio & 2.296 & 1.798 & 1.893 & 1.600 & 1.897 \\
\hline \multirow[t]{3}{*}{ Totals } & Males & 1883 & 1669 & 428 & 167 & 4147 \\
\hline & Females & 1529 & 1521 & 384 & 166 & 3600 \\
\hline & Sex ratio & 1.231 & 1.097 & 1.115 & 1.006 & 1.152 \\
\hline
\end{tabular}


sample. (We accept $\mathrm{p} \leqslant .02$ as the minimum acceptable level of significance.) The largest differences appear to be in the 21-30 age class, which shows there is an elevation of the frequency of group $O$, and a decrease in group $A$. Thus, there is an indication that group $\mathrm{A}$ decreases with advancing age and that this is at the expense of group $\mathrm{O}$; a regression analysis of blood groups $A$ and $O$ on age was run. The results of this regression analysis are listed in table 2. However, the regression of group A on the age groups 1-10 through 61-70 does not reach an acceptable level of significance and there is no evidence that group $\mathrm{O}$ is significantly correlated with age.

TABLE 2

\begin{tabular}{|c|c|c|c|c|}
\hline \multicolumn{5}{|c|}{ Regression analysis } \\
\hline SOURCE & s. s. & j). $\mathrm{r}$. & it. s. & $\mathbf{F}$ \\
\hline \multicolumn{5}{|c|}{ A on Age Groups 1-10 to 61-io } \\
\hline Regression & 9.0262 & 1 & 9.0262 & 4.8971 \\
\hline Residual & 9.2154 & 5 & 1.8430 & \\
\hline Total & 18.2416 & 6 & & \\
\hline \multicolumn{5}{|c|}{$.05<\mathrm{p}<.10$} \\
\hline \multicolumn{5}{|c|}{ O on Age Groups $1-10$ to $61-70$} \\
\hline Regression & .0305 & 1 & .0305 & .0057 \\
\hline Resiclual & 26.5897 & 5 & 5.3179 & \\
\hline Total & 26.6202 & 6 & & \\
\hline \multicolumn{5}{|c|}{$\mathrm{p}>.10$} \\
\hline
\end{tabular}

The chi-square for homogeneity of age groups versus blood groups was partitioned in order to discover the cells which contributed most to the total. Table 3 is a summary of the division of the total chi-square into three groups of three partitions. This analysis implies that the crucial comparison is between blood groups $\mathrm{O}$ and $\mathrm{A}$.

A test of sex and age versus the four blood groups was performed in order to pin-point the group which contributes most to the significance values. The sex ratios, male to fomale, for each age and blood group are included in table 1. It is interesting that the sex ratios decrease in the middle age groups. Table 4 summarizes the series of chi- 
TABLE 3

Blood groups versus age groups (Partitioned)

\begin{tabular}{|c|c|c|c|}
\hline PARTITION & CHI-SQUARE & D. F. & PROBABILITY \\
\hline$O: A$ & 24.6269 & 8 & $\mathrm{p}<.01$ \\
\hline $\mathrm{O}+\mathrm{A}: \mathrm{B}$ & 6.8805 & 8 & $.50<\mathrm{p}<.70$ \\
\hline$O+A+B: A B$ & 10.7908 & 8 & $.20<\mathrm{p}<.30$ \\
\hline SUM & 42.2982 & 24 & $.01<\mathrm{p}<.02$ \\
\hline $\mathrm{O}: \mathrm{B}$ & 10.3444 & 8 & $.20<\mathrm{p}<.30$ \\
\hline $\mathrm{O}+\mathbf{B}: \mathbf{A B}$ & 13.8983 & 8 & $.05<\mathrm{p}<.10$ \\
\hline $\mathrm{O}+\mathrm{B}+\mathrm{AB}: \mathrm{A}$ & 18.1192 & 8 & $.01<\mathrm{p}<.02$ \\
\hline SUM & 42.3619 & 24 & $.01<\mathrm{p}<.02$ \\
\hline$----\cdots--$ & --- & -- & ---- \\
\hline $\mathbf{A}: \mathbf{B}$ & 6.1967 & 8 & $.50<\mathrm{p}<.70$ \\
\hline$A+B: A B$ & 8.5777 & 8 & $.30<\mathrm{p}<.50$ \\
\hline$A+B+A B: O$ & 27.1636 & 8 & $.02<\mathrm{p}<.05$ \\
\hline SUM & 41.9380 & 24 & $.02<\mathrm{p}<.05$ \\
\hline
\end{tabular}

TABLE 4

Age and sex versus blood groups (Test of Homogeneity)

\begin{tabular}{|c|c|c|c|}
\hline AGE GROUPS & CHI-SQUARR & D. $\mathbf{F}$. & PROBABILITY \\
\hline $0-1$ & .4474 & 3 & $.90<\mathrm{p}<.95$ \\
\hline $1-10$ & 1.1994 & 3 & $.80<\mathrm{p}<.70$ \\
\hline $11-20$ & 2.1979 & 3 & $.50<\mathrm{p}<.70$ \\
\hline $21-30$ & 48.2987 & 3 & .01 \\
\hline $31-40$ & 3.2760 & 3 & $.30<\mathrm{p}<.50$ \\
\hline $41-50$ & 1.4964 & 3 & $.50<\mathrm{p}<.70$ \\
\hline $51-60$ & 5.5820 & 3 & $.10<\mathrm{p}<.20$ \\
\hline $61-70$ & 2.4836 & 3 & $.30<\mathrm{p}<.50$ \\
\hline $71-$ & 8.9083 & 3 & $.05<\mathrm{p}<.02$ \\
\hline Sum & 73.8897 & 27 & $\mathrm{p}<.01$ \\
\hline $0-20$ & 3.8446 & 9 & $.90<p<.95$ \\
\hline $21-50$ & 53.0712 & 9 & $\mathrm{p}<.01$ \\
\hline $51-$ & 16.9739 & 9 & $.02<\mathrm{p}<.05$ \\
\hline Sum & 73.8897 & 27 & \\
\hline Total & 7.3992 & $\mathbf{3}$ & \\
\hline Heterogeneity & 66.4805 & 24 & $\mathrm{p}<.01$ \\
\hline
\end{tabular}

Heterogeneity chi-square without 21-30 age group

Sum 25.5909

Total 
square values calculated to test the distribution of age and sex against blood groups. The heterogeneity chi-square value, 66.4905 with 24 degrees of freedom, is significant $(p<.01)$. This implies sex and age differences in the blood group distribution in the sample. However, one of the age groups, 21-30, has a very large chi-square. Collecting chi-squares into three age groups demonstrates that the 51 and older group also produces a value which suggests significance but falls below our accepted level. Removing the 21-30 age group reduces the total heterogeneity chi-square and it is no longer significant (table 4).

Statistical tests which we have applied to the data thus far suggest a scrutiny of age group 21-30 may reveal associations between blood group $\mathrm{O}$ and disease. A large variety of different diagnoses were grouped into very general classes in order to make tests of the distribution possible. The class gastro-intestinal disorders includes all diagnoses which involve the gastro-intestinal tract as the major site of disease. All traumatic diagnoses and ailments or surgery due to malformations of the gastro-intestinal tract were not included in this class. Each diagnostic class was constructed using similar principles.

Males and females of the age group 21-30 differ from each other significantly with respect to the frequencies of the ABO blood groups. In order to determine whether they differ significantly this way for each diagnostic class, a chisquare was run for each of the three classes with enough members to permit such a test: gastro-intestinal disorders, genito-urinary tract disorders, and elective surgery. The chi-square, 9.9320 with 3 degrees of freedom for the distribution of blood groups between the sexes in the class gastrointestinal tract disorders is significant $(.01<\mathrm{p}<.02)$. The other values are not. In this diagnostic class it is clearly the ratio of blood group $O$ to blood group $A$ that differs from expectations. If this ratio is found among all age groups, then it is legitimate to infer that a selective mechanism may be reponsible. 
The absolute numbers of gastro-intestinal disorders in each age group classified by sex and blood group are listed in table 5. A test of the ratio of blood group 0 to blood group $A$ in each sex in each group was performed. The class 71 years and older is too small for a meaningful test of significance. The significant results are summarized in table 6 . The chi-square values imply that the ratio of blood group $O$ to group $A$ is significantly higher in males than females between the ages of 21 and 60 . It is unfortunate that we cannot break down the diagnostic classes into groups precisely defined by the site of lesion, rupture, ulcer, tumor, etc. The

TABLE 5

Blood groups in gastro-intestinal disorders classified by age and sex

\begin{tabular}{|c|c|c|c|c|c|c|}
\hline AGE GROUPS & $\operatorname{sex}$ & 0 & $\mathbf{A}$ & $\mathbf{B}$ & $\mathrm{AB}$ & TOTAIS \\
\hline \multirow[t]{2}{*}{$0-1$} & Males & 25 & 29 & 6 & 2 & 62 \\
\hline & Females & 14 & 13 & 9 & 3 & 39 \\
\hline \multirow[t]{2}{*}{$1-10$} & Males & 10 & 13 & 2 & 3 & 28 \\
\hline & Females & 5 & 6 & 1 & 1 & 13 \\
\hline \multirow[t]{2}{*}{$11-20$} & Males & 18 & 9 & 4 & 1 & 32 \\
\hline & Females & 14 & 7 & 1 & 1 & 23 \\
\hline \multirow[t]{2}{*}{$21-30$} & Males & 102 & 29 & 6 & 3 & 140 \\
\hline & Females & 18 & 14 & 6 & 1 & 39 \\
\hline \multirow[t]{2}{*}{$31-40$} & Males & 50 & 14 & 6 & 2 & 72 \\
\hline & Females & 18 & 20 & 5 & 3 & 46 \\
\hline \multirow[t]{2}{*}{$41-50$} & Males & 105 & 32 & 7 & 3 & 157 \\
\hline & Females & 36 & 38 & 5 & 5 & 84 \\
\hline \multirow[t]{2}{*}{$51-60$} & Males & 97 & 50 & 10 & 4 & 161 \\
\hline & Females & 29 & 38 & $\tilde{3}$ & 3 & 75 \\
\hline \multirow[t]{2}{*}{$61-70$} & Males & 62 & 30 & 9 & 4 & 105 \\
\hline & Feinales & 16 & 13 & 3 & 3 & 35 \\
\hline \multirow[t]{2}{*}{$71-$} & Males & 35 & 20 & 2 & 2 & 59 \\
\hline & Females & 6 & 5 & 1 & 1 & 13 \\
\hline \multicolumn{7}{|l|}{ Totals } \\
\hline & Males & 504 & 296 & 52 & 24 & 816 \\
\hline & Females & 156 & 154 & 36 & 21 & 367 \\
\hline
\end{tabular}


TABLE 6

Blood groups in gastro-intestinal disorders Test of sex ratio elassified by groups $O$ and $A$

\begin{tabular}{|c|c|c|c|}
\hline AGE GROUPS & CHI-SQUARE & D. F, & PROBABIIITY \\
\hline $0-1$ & 0.222 & 1 & $.80<\mathrm{p}<.90$ \\
\hline $1-10$ & .0118 & 1 & $.90<\mathrm{p}<.95$ \\
\hline $11-20$ & .0000 & 1 & \\
\hline $21-30$ & 6.1852 & 1 & $.01<\mathrm{p}<.02$ \\
\hline $31-40$ & 10.5771 & 1 & $\mathrm{p}<.01$ \\
\hline $41-50$ & 16.8808 & 1 & $\mathrm{p}<.01$ \\
\hline $51-60$ & 9.7971 & 1 & $\mathrm{p}<.01$ \\
\hline $61-70$ & 1.9854 & 1 & $.10<\mathrm{p}<.20$ \\
\hline
\end{tabular}

TABLE 7

Women transfused because of pregnancy related disorders

\begin{tabular}{|c|c|c|c|c|c|}
\hline AGK GROUPS & 0 & $A$ & $\mathbf{B}$ & $A B$ & TOTALA \\
\hline $11-20$ & 8 & 12 & 2 & 0 & 22 \\
\hline $21-30$ & 62 & 89 & 26 & 10 & 187 \\
\hline $31-40$ & 27 & 48 & 11 & 7 & 93 \\
\hline $41-50$ & 3 & 7 & 2 & 2 & 14 \\
\hline Totals & 100 & 156 & 41 & 19 & 316 \\
\hline \multicolumn{6}{|c|}{$\begin{array}{l}\text { Chi-square (transfused pregnant women vs. } \\
\text { all other transfused women) }=14.8669,1 \mathrm{D} \text {. F. } \\
\qquad \mathrm{p}<.01\end{array}$} \\
\hline
\end{tabular}

information was not available for this. Yet we suspect that males suffering from ulcers and experiencing hemorrhagic episodes may account for many of the individuals in this general category. If this is so, the trend, discussed by Aird et al. ('54), Westlund and Heisto ('55), and Clarke et al. ('56), for males of group 0 to be more susceptible to peptic ulceration is borne out. However, these data cannot be used directly to support this view.

The deviations in the pattern of the sex ratios suggest it might be well to investigate the distributions of blood groups among women in this sample who required transfusions because of disorders associated with pregnancy. The absolute numbers of women in this class in age groups 11-20, $21-30,31-40$, and $41-50$ are listed in table 7 . It can be shown, 
with a chi-square test of ages against blood groups and blood groups against ages, that the trend found in women of age group 21-30 is present in the other age groups. Precisely, the distribution of ages against blood groups and blood groups against ages is not significantly heterogeneous for the four classes considered. The frequency of group $\mathrm{O}$ among all these women suffering from pregnancy associated difficulties is $31.64 \%$, which is below the frequency of group 0 women in the total sample. These women can be classified into two groups, those possessing an antigen capable of stimulating an antibody reponse and those who do not. Of those requiring transfusions because of pregnancy, $68.36 \%$ are in the former class. A comparison between all other women requiring transfusions and the women in the category pregnancy disorders was made. A chi-square test of the difference between these two classes is summarized in table 7. The two values are significant. This implies that the divisions between group $O$ women on the one hand and group $A, B$, and $A B$ women on the other, with respect to pregnancy disorders requiring transfusions, is related to the illnesses included in that class. Despite the suggestion that there is a difference in attack rates for males and females for various diseases, the sex ratio differences in our sample are puzzling. The highest sex ratio in this sample (table 1 ) is in the first two age groups in individuals of groups $O$ and $A$. Further study of the sex ratio at birth related to the loss of certain $\mathrm{ABO}$ groups due to maternal-fetal serological incompatibility is suggested.

The sample reported here has certain special characteristics; therefore, it would be unwise to generalize from it too widely. It represents a sub-group of sick people; those requiring blood transfusions. The patients were referred to the hospital from the entire state of Michigan, though analysis of the residence composition of the sample indicated that less than 5\% came from outside the Lower Peninsula. In spite of special features, the distribution of the $A B O$ types is heterogeneous within the sample and there is evi- 
dence that it is heterogeneous because of factors related to disease and, hence, to natural selection.

A control population should be sampled for comparisons. Controls for data on admissions to a referral hospital are extremely difficult to obtain. Blood donors to hospital blood banks are unsatisfactory for a number of reasons. The age and sex distributions are not normal and such a sample is selected to match the recipients in blood type.

Hervey, Diamond and Watson ('51) published the results of a nationwide Red Cross blood bank drive conducted during the years 1948 and 1949. The information they

TABLE 8

$A B O$ distribution of hospital patients compared with Detroit area donors

\begin{tabular}{|c|c|c|c|c|c|c|}
\hline SOURCE & & o & $A$ & B & $A B$ & TOTALS \\
\hline \multirow{2}{*}{ Patients } & Number & 3412 & 3190 & 812 & 333 & 7747 \\
\hline & Percent & 44.04 & 41.18 & 10.48 & 4.30 & 100.00 \\
\hline \multirow{3}{*}{ Donors } & Number & 2396 & 2350 & 683 & 299 & 5728 \\
\hline & Percent & 41.83 & 41.03 & 11.92 & 5.22 & 100.00 \\
\hline & \multicolumn{5}{|c|}{ Chi-square $=15.8742,3$ D. F. } & \\
\hline
\end{tabular}

provide about the composition of the regional samples indicates they are more representative of the healthy population at large, at least with respect to age distribution, than are donors to hospital blood banks.

The figures for the Detroit area published in the above survey were used as a control for comparative purposes. The majority of individuals in this control group were males, persons in the industrial, clerical and professional classes of the white population. It seems reasonable to conclude this is a sample of healthy individuals from the same general population from which the sample of sick people came. The difference in frequency of the blood groups is significant and suggests that further investigation of the sick versus healthy classification of $\mathrm{ABO}$ frequencies is warranted. The results of this analysis are in table 8 . 
The comparison of the hospital sample with the healthy donor sample from the Detroit area raises a number of statistical questions since the differences in $\mathrm{ABO}$ frequencies between the two samples are significant. If the two samples represent the same general population, then the differences indicate that there is differential susceptibility to illness with respect to the $A B O$ blood groups. It has been claimed that differences in $\mathrm{ABO}$ frequencies such as this are due to ethnic stratification of the populations or samples compared (Wiener, '43; '56). The unlikelihood of ethnic stratification with respect to the demonstrated associations between group $\mathrm{O}$ and peptic ulceration and group $\mathrm{A}$ and gastric carcinoma has been discussed by Clarke et al. ('56). It does not seem reasonable that the Detroit area donors and the University Hospital patients represent different ethnic stratifications of a sufficient magnitude to affect significantly the blood group frequencies. We cannot settle this point and thus must exercise caution in generalizing from the differences.

\section{DISCUSSION}

At present three associations between disease and the ABO blood groups-secretor-complex have been demonstrated. These are: peptic ulceration and blood group $\mathrm{O}$ and the secretor factor (Aird et al., '54; Westlund and Heisto, '55; Clarke et al., '56), gastric carcinoma and blood group A (Aird et al., '54; Køster et al., '55; Buckwalter et al., '56; Jennings et al., ' 56 ; Billington, ' 56 ), and the rheumatic sequelae of streptococcus infections of the throat and secretion of ABO antigens in the saliva and gastric juice (Glyn et al., '56).

The data reported in this study support but do not confirm the trends demonstrated by these investigators. While many of the patients included in the sample that were classified as having gastro-intestinal disorders certainly suffered from peptic ulceration, our classification system cannot give exact frequencies.

The fact that group A was significantly reduced in frequency in the class gastro-intestinal disorders is apparently 
a direct consequence of the association of group $O$ with peptic ulcers which, of course, is unexpected in the light of the association previously discovered with gastric carcinoma. This is probably due to the small number of cases of gastric carcinoma, since there were less than a hundred in our sample.

What explanation have we for the association between group $\mathrm{O}$ and gastro-intestinal disorders? We might expect such an association to be related to properties of the group specific substances themselves. If there are differences in the protection against disease and inflammation which the three substances afford, then it is not unexpected that group $O$ is associated with increased morbidity. The ABO group specific substances are present in large volume and high titer in the gastro-intestinal tract, in the saliva, bile and gastric juice of about $80 \%$ of the individuals in European populations (Hartmann, '41; Kabat, '56) and they have recently been found on the surface of tissue cells (Coombs et al., '56). Such individuals possess a dominant gene for the secretion of the substances in water soluble form (Schiff and Sasaki, '32). The A and B substances are well known (Pardee and Blaker, '51; Morgan, '56). The substance associated with the $O$ gene has recently been demonstrated (Morgan and Watkins, '48) and its chemical composition has been determined (Kabat, '56). There are large differences in molecular weights among the three. The $A$ and $O$ substances have significantly lower weights than the $\mathrm{B}$ substance. If inflammation and cancer are related to the permeability of the cell wall, as Eyring and Dougherty ('55) suggest, then it is possible that the group specific substances are differentially related to mechanisms which protect the tissue cells of the gastro-intestinal tract. The heavier molecule, group specific substance $B$, is assumed to afford the greater protection against permeability. This suggestion, is, of course, speculative. It is, nonetheless, based on actual physicochemical differences in the tissues of the four $\mathrm{ABO}$ phenotypes. 
Our data indicate that women of groups $A, B$, and $A B$ suffer a morbid risk significantly greater than group $\mathbf{O}$ women. These two classes of women differ with respect to two things. Group $O$ women possess an antigen that does not seem capable of stimulating an antibody response and two naturally occurring antibodies circulate in their serum. Group $\mathrm{A}, \mathrm{B}$, and $\mathrm{AB}$ women possess antigens capable of stimulating antibody production and have one or no naturally occurring antibody. Whether these differences are related to the increased morbid risk discovered for the former class is unknown. The secretor status of the woman and her fetus, whether she is part of a heterospecific mating, and whether she has been immunized against the $\mathrm{RH}$ antigens are other factors to be considered (Smith, '45; Levine, '57).

The analysis of the data in this report suggests that there are factors related to natural selection which affect the $A B O$ phenotypes. The classification of the $A B O$ frequencies by age and sex indicated differential susceptibility to certain morbid conditions; gastro-intestinal disease and pregnancy disorders. The significant differences in the $\mathrm{ABO}$ frequencies between healthy controls and the hospital sample imply that the physical fitness, age, and sex of individuals in samples taken for blood group surveys of populations are data which must be collected in the future.

\section{SUMMARY}

Examination of the age and sex composition of a sample of 7747 hospital patients receiving blood transfusions showed significant heterogeneity within the sample with respect to age and sex. Analysis of the significance showed that the ratio of blood group 0 to blood group $A$ was significantly elevated in males suffering from gastro-intestinal disorders. The ratio of group 0 to groups $A, B$, and $A B$ was significantly reduced among females suffering from pregnancy related disorders. Comparison with a sample of healthy individuals from the same general area showed significant dif- 
ferences from the sample of transfused patients. The significance of the findings was discussed.

\section{LITERATURE CITED}

Aird, I., H. H. Bentali AND J. A. Fraser Roberts 1953 A relationship between cancer of the stomach and the ABO blood groups. B. M. J., 1: $799-801$.

Boyd, W. C. 1939 Blood groups. Tabulae Biologae, Hague 17: 113-240.

- 1953 The contributions of genetics to anthropology. In Anthropology Today, edited by Sol Tax. Chicago: University of Chicago Press.

Birlington, B. P. 1956 Gastric cancer. Laneet, 2: 859-862.

BRUES, A. M. 1952 Selection and polymorphism in the A-B-O blood groups. Am. J. Phys. Anthrop., n. 8., 18: 559-597.

Buckwalter, J. A., E. B. Wolluwend, D. C. Colter and R. T. Tidrick 1956 Natural selection associated with the ABO blood groups. Science, 123: 840-841.

Clarke, C. A., J. W. Edwards, D. R. W. Haddock, A. W. Howel-Evans and R. B. MCCONNELL 1955 The relationship of the ABO blood groups to duodenal and gastric ulceration. B. M. J., 2: 643-646.

Coombs, R. R. A., D. Bedford AND L. M. Routllakd 1956 A and B blood group antigens on human epidermal cells. Lancet, 1 : 461-463.

Diknst, A. 1905 Das Eklampsiegift. Zentr. f. Gynäk., 29: 353-364.

Ehrilch, P., AND J. Morgenroth 1900 Ueber Hamolysine. Berl. Klin. Wochsehr., $37: 453-458$.

EyriNg, H., AND T. DougherTy 1955 Molecular mechanisms in inflammation and stress. I. Amer. Seientist, 45: 457-467.

Glass, B, 1954 Genetic changes in human populations, especially those due to gene flow and genetic drift. Advances in Genetics, $6: 96-139$.

Glynn, A. A., L. E. GLynn and E. J. Holbrow 1956 The secretor status of rheumatic-fever patients. Lancet, 2: 759-762.

HARTMANN, G. 1941 Group antigens in human organs. Copenhagen: Munksgaard.

Hervey, G. W., L. K. Diamond and V. Watson 1951 Geographic blood group variability in the United States. J. A. M. A., 145: 80-81.

HirszFeld, L., aNd H. HirszFend 1919 Serological differences between the blood of different races. The result of researches on the Macedonian front. Lancet, $2: 675-679$.

Jennings, D., R. H. Balme and J. E. Richardson 1956 Carcinoma of the stomach in relation to ABO blood-groups. Lancet, 2 : 11-12.

Kabat, E. A. 1956 Blood group substances. New York: Academic Press.

K $\emptyset$ ster, K. H., E. Sindrup AND V. SEele 1955 ABO blood-groups and gastric acidity. Lancet, $\mathcal{Z}: 52-55$.

I.EVINE, P. 1957 The influence of the ABO system on RH hemolytic disease. Read at 10th Annual Meeting, American Society of Human Genetics, Ann Arbor, Michigan. 
Limpanan, W. 1905 Zur Dienst'sehen Eklampsietheorie. Zentr. f. Gynäk., 29: 481-486.

Manulla, A. 1956 Distribution of A-B-O genes in eastern Europe. Am. J. Phys. Anthrop., n. s., 14: 577-588.

Morgan, W. T. J. 1956 Blood group substances. In Polysaceharides in Biology, ed. by G. F. Springer, New York: Josiah Macy.

Morgan, W. T. J., AND W. M. Watkins 1948 The detection of a product of the blood group $O$ gene and the relationship of the so-called $O$ substance to the agglutinogens $A$ and B. Brit. J. Exptl. Pathol., 29: 159-173.

Pardee, A. B., ANd R. H. Blaker 1951 Size and shape of blood-group A substance. Proc. Soc. Expt1. Biol. Med., 78: 589-590.

SCHIFY, F., AND H. SASAKI 1932 Der ausscheidungstypus, ein auf serologisehen wege nachweisbares Mendelndes merkmal. Klin. Wochsehr., 34: 14261429.

SMITH, G. H. 1945 Iso-agglutinin titres in heterospecific pregnancy. J. Pathol. Bacteriol., 5 : 223-228.

VERZAR, M. F. 1922 Isohaemagglutination in anthropology. Inst. Inter. d'Anthrop., $3: 419-426$.

Westutund, K., AND H. Heistö 1955 Blood groups in relation to peptie ulecration. B. M. J., $1: 847$.

WIENER, A. S. 1943 Blood groups and Transfusion. Springfield, Illinois: Charles C Thomas.

1956 Blood groups and disease. Lancet, $2: 1308$. 